\title{
The Effect of Corporate Governance, Green Strategy and Carbon Risk Management Toward Carbon Emission Disclosure (Listed Company in and Out on Calculation Indeks Sri Kehati in IDX Periode 2016 - 2017)
}

\author{
Sindi Marta Tila \\ Yvonne Augustine \\ Bussines and economics faculty, Trisakti University \\ Jl. Kyai Tapa No.1, Tomang, Grogol petamburan, Kota Jakarta Barat, Daerah Khusus Ibukota Jakarta 11440
}

\begin{abstract}
The object of this study is to investigate the influence of the effect of carbon emissions disclosure whether corporate governance characteristics impact, and green strategy. This empirical study was conducted out in three part. The relationship between corporate governance and carbon emission disclosure, the relationship between green strategy and carbon emission disclosure and the relationship between carbon risk management and carbon emission disclosure. This study uses samples obtained through annual sustainability reports and annual reports from the Sri Kehati Index listed on the Indonesia Stock Exchange (IDX) during 2016-2017. The research sample are 30 firms with 60 observations which listed companies listed on IDX during 2016-2017. In order to meet the objective of this research, researcher has used double declined regression model to explore the implication and correlation in both assumptions. This research differs from previous research with the addition of a sustainability committee and green strategy in the component of corporate governance. The results of this empirical study show that corporate governance issues with diversity boards, board independence, board size, and sustainability committees have a positive influence on disclosure of carbon emissions and add to this disclosure and carbon risk management has a positive impact on carbon emissions disclosure. This study provides empirical evidence about various factors that can affect carbon emissions disclosure, which can be useful for stakeholders both companies and investors. The importance of this research can contribute so that companies are able to take policies in order to reduce carbon gas emissions in climate pollution. Carbon risk management in this study discusses carbon efficiency and carbon emissions in the future, and also future carbon that can be done or planned that is designed to manage the risks of carbon emissions effectively and efficiently. This research discusses the influence of relationship between corporate governance, green strategy and carbon risk management that is needed by companies to see the impact on disclosure of carbon emissions specifically.
\end{abstract}

Keywords: Corporate Governance, Board diversity, Board Size, Board Independence Board diversity, Sustanability Committee, Green Strategy, Carbon Emission Disclosures, and Cabon risk management.

DOI: $10.7176 / \mathrm{EJBM} / 11-23-06$

Publication date: August $31^{\text {st }} 2019$

\section{Introduction}

An example of bad corporate governance can be seen when Indonesia experienced a crisis in 1997 and many companies failed at that time. The crisis in Indonesia results from a lack of transparency and relevant information that can be relied upon as a form of quality for the company's annual report. According to Agoes (2011) good governance is a system that regulates the role of the Board of Directors, shareholders and other stakeholders through a transparent process to achieve company goals. Disclosure of relevant information will also produce higher asymmetric information so as to make the company value higher and vice versa.

Global warming and climate change because carbon emissions have become very serious issues and threaten the future of humans, the lack of concern from large companies makes the issue of global warming more serious. The board of directors of the company was asked to propose several actions related to the issue of global warming (Prado-Lorenzo et al., 2009). In addition, the government discussed with environmental groups to establish regulations on greenhouse gas (GHG) emissions and proactive and positive measures on carbon emission strategies (Reid and Toffel, 2009).

In increasing attention to the development of issues of carbon emissions, several effects were created on the disclosure of carbon emissions. So stakeholders must respond seriously and develop proactive strategies for environmental problems and disclosure of carbon emissions. Sustainable and Responsible Investment (SRI) - the KEHATI stock index is one index which is an indicator of stock price movements on the Indonesia Stock Exchange (IDX), which uses the principles of sustainability, finance, and good governance, as well as concern for the environment as its benchmark .

This index was launched on June 8, 2009 by the Indonesian Biodiversity Foundation (KEHATI) in collaboration with IDX. The SRI-KEHATI Index is a benchmark for investors and investment managers in seeing 
good corporate performance in conducting their business in terms of good corporate governance including in terms of financial, social and environmental sustainability.

Carbon emission disclosure in Indonesia is still voluntary disclosure. The company began to disclose carbon emissions for the interests of stakeholders with the aim of increasing transparency and accountability of the company. But not a few companies are holding back the disclosure of carbon emissions because this information may require a large amount of money and is considered to be detrimental to the company. Beside that, some of studies have investigated the impact of characteristics in good corporate governance such as board size, board diversity board independence and suistanability committee, and board gender of corporate which reporting practices relative to carbon emissions (Ben-Amar et al., 2017). Research studies on the relationship between board diversity and disclosure of carbon emissions have also not been widely carried out (Hollindale et al., 2017). Thus, the purpose of this study is to see the extent to which carbon risk management has been developed including the disclosure of carbon emissions and strategies in implementing carbon risk management.

(Andersson et al., 2013) revealed that green strategies have been studied by scholars from various disciplines related to strategy, operations and accounting. Green strategy cheklist will support the existence of carbon risk disclosure. In additon, the purpose of this study is to look at the positive relationship between the level of carbon emissions disclosure, the green strategy checklist in Indonesia and corporate governance including board diversity, board size, board independence, and sustainability committees.

\section{The Hypothesis and the Variables}

2.1 The Relationship Between Board Size and Carbon Emmision Disclosure

The board of directors as top management is responsible for developing the company's sustainability in business strategies to oversee the use of company assets wisely (Jizi et al., 2014). In addition board director exists for ensuring the material of environmental risks are well-monitored and full of disclosure (Ben-Amar et al., 2017).

According to Ben-Amar, et al. (2017) the board of directors serves to look at company-owned risks and monitor them well and are full of disclosures (Ben-Amar et al., 2017). Thus, more directors owned by a company to take action will increase the monitoring capacity of the board and the ability to promote value creation activities (Akhtaruddin et al., 2009).

Companies with larger councils may be stronger to deal with issues related to carbon emissions disclosure and more strategic in decision making. The results of the study of Liao et al. (2016) towards a positive and significant relationship between board size and carbon emissions disclosure. Then, the hypothesis taken by researchers:

H1 : Board size has a positive significant impact on carbon emission disclosures.

\subsection{The Relationship Between Board Independence and Carbon Emmision Disclosures}

Good corporate governance in reducing problems that occur between agency and management and shareholders depending on board independence. the independent director will increase activities to change the business strategy of the company and disclose carbon emissions in many aspects. Jizi et al., (2014) revealed that an independent council is expected to be an important part in the success of supervision of management in terms of maintaining the value of high transparency and long-term value.

Yunuset al., (2016) also revealed that independent councils prove the social demands of the community will have a sensitive impact on the company's business and inhibit the focus on short-term results. The results of the study from Yunus et al., (2016) revealed that there was a significant positive relationship between the independence of the board on disclosure of carbon emissions. So, the research hypothesis based on the description above is:

H2 : Board independence has a positive significant impact on carbon emission disclosures.

\subsection{The Relationship Between Board Diversity and Carbon Emission Disclosures}

According to Barako and Brown (2008) good corporate governance has an important component, namely the diversity of the board. There are several factors to support the positive relationship between the board's gender diversity and good corporate governance.

First, recruiting more women in the board structure and discussion (Barako and Brown, 2008). Bear et el., (2010) revealed that decision making can be seen from a broader perspective and is able to improve communication between the board of directors. Second, identification of problems and business strategies among stakeholders in the company would be better if the company had broader knowledge (Harjoto et al., 2015). Bear et al., (2010) revealed that the existence of female directors was able to provide judgments and make better decisions among stakeholders' needs.

Ben-Amar et al. (2017) revealed that recruiting women to become directors on the company's board would increase sensitivity to environmental issues to increase company value. The results of the study from Liao et al. (2015) and Hollindale et al. (2017) a positive impact on the relationship between board gender diversity and 
disclosure of carbon emissions. so that it can be concluded that the company with a greater proportion of women are able to disclose carbon emissions better through communication between the board of directors and stakeholders. Therefore, the hypothesis based on the description above is:

H3 : The board diversity has a positive significant impact on carbon emission disclosures.

2.4 The Relationship Between Sustainability Committees and Carbon Emission Disclosures

Rankin et al., (2011) The important thing about the internal organization system is the credibility of controls, measurement, recording and disclosure of carbon emissions in regulatory requirements and actions that change expectations in social demands. In addition, according to Yunus et al., (2016) the environmental committee is motivated by a reputation based on management's reputation with the aim of implementing rules and practices for measuring and reporting levels of disclosure of carbon emissions as a way to reduce the issue of global warming. So, the hypothesis based on the description above is:

H4 : Sustainability committee has a positive significant impact on carbon emission disclosures.

\subsection{The Relationship Between Carbon Risk Management and Carbon Emission Disclosure}

This study discusses about carbon risk management and carbon efficiency and carbon emissions in the future, and also future carbon risk that can be done or planned that is designed to manage the risks of carbon emissions effectively and efficiently, while viewed from the perspective theory shows a relationship between carbon risk management and carbon emissions disclosure.

There are fundamental differences in disclosure in previous theories are different, because according to Clarkson, et al., (2011) it is difficult to discuss company information that is lower to soft disclosure to improve their image and economic-based information, it is difficult to replicate their performance. The higher the quality of carbon emissions disclosure, the better the disclosure of carbon emissions. So, the hypothesis based on the above description is:

H5 : Carbon risk management has positive significant on quality of carbon disclosure.

\subsection{The Relationship Between Green Strategy and Carbon Emission Disclosure}

The model of a green strategy is considered to be less relevant because of an imperfect framework. Green strategy itself is considered as part of the overall social strategy without autonomous relevance and is not optimal if it can integrate the following:

- Some perspective strategies about environmental strategies;

- Strategic processes that consider many elements of the formulation and implementation steps;

- Thought about considering the relationship between environmental strategy, company financial performance and environmental ecosystem results.

De Villiers and Van Staden (2010) revealed that CEOs as decision makers to adopt the above framework for decision-making processes towards green management strategies. First, there is the influence of green management in relation to the steps of formulating a strategic process. Second, there is a balance between strategy and action on the environment in the implementation process. Third, how to achieve results from environmental performance that have a direct effect because of strategic actions in the biophysical environment. So that it will produce competitive finance related to environmental performance that is better in revenue, and companies are able to manage costs and competitive advantage.

H5 : Green Strategy has positive significant impact to carbon emission disclosure

\section{Measurement Variable And Reserach Model}

\subsection{Measurement Variable}

\subsubsection{Dependent variables}

Measurements about carbon emission disclosure trends are measured through two proxies. First, it is done through a content analysis approach used to investigate disclosure of carbon emissions from these entities. Second, it is done through a non-weighted (binary) index that will be designed to be an annual report. Thus, the disclosure of each entity on each item represented by a score is set as 1 , and 0 otherwise. Thus, measurements of Cabon emission disclosure (CDI) amounted to 20 items. The results of this measurement are used to measure the level of carbon emissions disclosure provided by the entity. The carbon emission disclosure score is calculated by dividing the items disclosed below. Thus, the total CDI score is formulated from Luo et al., (2013) as follows:

$$
\mathrm{CDI}=\frac{\sum_{i=1}^{t} e}{t}
$$

$\mathrm{Ci}=0$ or $1:$

$\mathrm{Ci}=0$ (if the disclosure item was not found)

$\mathrm{Ci}=1$ (if the disclosure item was found)

$\mathrm{t}=$ the maximum number of carbon emission disclosure items a firm could disclose 


\subsubsection{Independent variables}

\subsubsection{Corporate Governance}

The directors of independent directors are divided by the total number of directors in the company. Board size is measured as the total number of members of the board of directors in the company. The gender diversity of the board measures the percentage of female directors. Board gender in this case is calculated through the number of women divided by the number of directors, the number of women who show more homogeneity in terms of gender in the company. Good corporate governance related to the board of directors will influence decision making.

\subsubsection{Green Strategy}

In this research, green strategy is calculated through the completeness of the green strategy checklist, namely strategic processes, implementation, environmental performance, and financial competitive performances. Analysis of the influence of green management is divided into four dimensions. First, it is assessed from the formulation of a green strategy in the integration of the legitimacy and importance of the biophysical environment in the steps to formulate appropriate strategic processes to be implemented. Second, a balance between strategies and actions for the environment so that they can be implemented. Third, to achieve results in the environment related to environmental performance and the direct influence of strategic actions on the biophysical environment. Fourth, financial results and competition related to the influence of better environmental performance on income, competitive advantage and costs.

\subsubsection{Carbon Risk Management}

Analysis of carbon emissions disclosures has potential risks and opportunities. These risks and opportunities are not based solely on category 1 of the CDI method but come from various categories. This category is assessed based on how they are able to manage risks and opportunities and how they are able to adapt including minimizing existing risks. The risks and opportunities that exist relate to aspects of the potential risks that exist from the construction of carbon risk management.

So that the score of carbon risk mangement is based on the carbon emission disclosure performance appraisal system, this process is used because carbon disclosure performance scores are not available for research. Based on the performance methodology of the CDI, the company will be given points based on actions taken to disclose carbon emissions and global warming. However, the CDI performance methodology might inadvertently measure the level of disclosure and performance.

The CDI performance methodology seeks to minimize problems by measuring and assessing performance based on material actions carried out by the company in managing disclosure of carbon emissions and global warming. Some companies, for example, are given points as a result of their recognition of the risks and opportunities associated with climate change. The company has an obligation to respond in the face of the risks and opportunities that occur due to disclosure of carbon emissions.

\begin{tabular}{|c|c|}
\hline Actions & Available Scores \\
\hline Risk \& Opportunities & 6 \\
\hline Emissions Accounting & 9 \\
\hline Verification \& Trading & 3 \\
\hline Performance & 13 \\
\hline Governance & 6 \\
\hline TOTAL & 39 \\
\hline
\end{tabular}

Source :

The table above shows the components of cabon risk management, the actual score to be achieved is 39 , with the following formula:

Final score $=($ score achieved $/$ score available $) * 100 \%$ 


\subsection{Research Model}

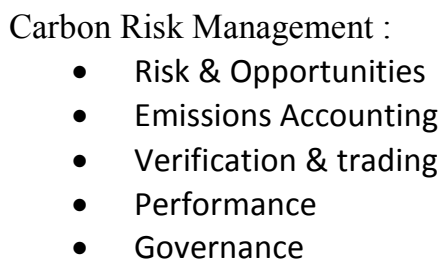

Carbon Risk Management :

- $\quad$ Risk \& Opportunities

- Emissions Accounting

- Verification \& trading

- Performance

- Governance

Corpoate Governance :

- Board Size

- Board Independence

- Board Diversity

- Sustainablity Committee

Green Strategy :

- $\quad$ Strategic Process

- Implementation

- Environmental Performance

- Financial \& Competitive performance

Data regression models are used to investigate the relationship between carbon risk management, green strategy, and corporate governance on carbon emissions disclosure. The model obtained by researchers is:

$\mathrm{CDI}=\alpha+\beta 1 \mathrm{SIZE}+\beta 2 \mathrm{BINDP}+\beta 3$ BGENDER $+\beta 4$ SCOM $+\beta 5 \mathrm{RISKOP}+\beta 6 \mathrm{EACT}+\beta$ VTRADE + $\beta 8$ PERFORM $+\beta 9$ GOV $+\beta 10$ MISVIS $+\beta 11$ GOALS $+\beta 12$ UNITPRO $+\beta 13$ ALLIANCE + $\beta 14$ BUSENTRY + $\beta 15$ POLLEXIT $+\beta 16$ POLLINVEST $+\beta 17$ GRINOV $+\beta 18$ ENVRISK $+\beta 19$ WASTERED $+\beta 20$ CONSMRED + $\beta 21$ ENVTRED $+\beta 22$ STDOPTION $+\beta 23$ EMISREDUC $+\beta 24$ FUDNSUP $+\beta 25$ ENVCOM $+\beta 26$ WASTERED 2 $+\beta 27$ CONSMREDUC $+\beta 28$ EMISREDUC $2+\beta 29$ AWARDS $+\beta 30$ INOVATION $+\beta 31 \mathrm{LAWS}+\beta 32$ ENVINCID $+\beta 33$ CERTIF $+\beta 34$ CERTIF $2+\beta 35 \mathrm{FBEF}+\beta 36 \mathrm{FCOSTS}+\beta 37 \mathrm{PQUALITY}+\beta 38 \mathrm{QPERCEP}+\beta 39 \mathrm{NEWCOMP}$ $+\varepsilon$

\section{Variables Operational definition}

Dependent variables

CDI The\%of total items a firm disclosed to total items (i.e. 20 items) in disclosure index

Independent variables

Board size (BSIZE)

Total number of directors on the board

Board independence (BINDP) The \%of independent directors to total number of directors on the board Board gender diversity (BGENDER) Sustainability committee (SCOM) Risk \& Opportunities (RISKOP) Emissions Accounting(EACT) Verification \& Trading(VTRADE) Performance (PERFORM) Governance (GOV) The \%of female directors to total number of directors on the board 1 if a firm had a sustainability committee, 0 otherwise Score : 6 (per total score 37 divided by $100 * 100 \%$ ) Score : 9 (per total score 37 divided by $100 * 100 \%$ ) Score : 3 (per total score 37 divided by $100 * 100 \%$ ) Score : 13 (per total score 37 divided by $100 * 100 \%$ ) Score : 6 (per total score 37 divided by $100 * 100 \%$ )

\section{GREEN STRATEGY}

- $\quad$ Strategy Process

Integrating green into vision \& mission (VISMIS)

Integrating green into strategic goals (GOALS)

Green units projects (UNITPRO)

Green strategy alliance

(ALLIANCE)

Green business entry (BUSENTRY)

Cheklist

Cheklist

Cheklist

Cheklist

Cheklist 
Pollutant business exit (POLLEXIT)

Cheklist

Green investments (POLINVST)

Cheklist

Green innovation (GRINOV)

Cheklist

Environmental risks (ENVRISK)

Cheklist

- Implementation

Environmental certifications (CERTIF)

Cheklist

Waste reduction actions (WASTERED)

Cheklist

Consumption reduction (CONSMRED)

Cheklist

Environmental impact reduction (ENVTRED)

Cheklist

Environmental standard adoption

(STDOPTION)

Cheklist

Emissions reduction (EMISREDUC)

Green initiatives funds \& supports (FUDNSUP)

Cheklist

Environmental communication (ENVCOM)

Cheklist

- Environmental performance

Waste reduction (WASTERED2)

Consumption reduction (CONSMRED2)

Emission reduction (EMISREDUC2)

Cheklist

Green awards (AWARDS)

Green innovation (INOVATION)

Green lawsuits, crimes, \& compensation (LAWS)

Cheklist

Cheklist

Cheklist

Cheklist

Cheklist

Environmental incidents (ENVINCID)

Cheklist

Environmental certifications (CERTIF2)

Cheklist

Cheklist

- Financial and Competitive performance

Financial benefit (FBEF)

Financial costs (FCOSTS)

Cheklist

Product quality (PQUALITY)

Cheklist

Quality perception (QPERCEP)

Cheklist

New competencies (NEWCOMP

Cheklist

Cheklist

3.3 Sample selection

the carbon disclosures data were sourced from the annual and stand-alone sustainability reports of The sample of this research is Indeks Sri Kehati firms which is listed on Indonesia Stock Exchange (IDX) over 2016-2017. The research sample are 30 firms with 60 observations. listed companies listed on IDX during 2016-2017.

Tabel I

Composition of the Sample by Industry Type

\begin{tabular}{|c|c|c|c|}
\hline Industry & Frecuency & Percentage & Code Comapany \\
\hline Agraria & 2 & $6,67 \%$ & AALI, LSIP \\
\hline Consumer Product & 3 & $10 \%$ & INDF, KLBF, UNVR \\
\hline Mining & 2 & $6,67 \%$ & PTBA, TINS \\
\hline Trading / Services & 2 & $6,67 \%$ & UNTR, PJAA \\
\hline $\begin{array}{c}\text { Property and Real } \\
\text { Estate }\end{array}$ & 5 & $16,67 \%$ & WSKT, ADHI, WIKA, BSDE, ASRI \\
\hline Finance & 5 & $16,67 \%$ & BBCA, BBNI, BBRI, BDMN, BMRI \\
\hline Variety Industry & 2 & $6,67 \%$ & ASII, GJTL \\
\hline $\begin{array}{c}\text { Infrastruktur, Utility, } \\
\text { and Transportation }\end{array}$ & 5 & $16,67 \%$ & JSMR, TLKM, EXCL, PGAS, GIAA \\
\hline TOTAL & 30 & $100 \%$ & \\
\hline
\end{tabular}

\section{Result and Discussion}

\subsection{Descriptive statistics}

The results of the descriptive statistics are shown in Table II. CDI ranged from 90 to 100 percent, indicating a substantial variation within the sample. The average mean of CDI was 0.983 , which implies that the level of carbon emission-related information disclosed by sample companies was quite high because the sample comes from index SRI-KEHATI. The BSIZE varied greatly across the sample, as the minimum was 4 and the maximum was 11 . The average board had 7.43 directors with a standard deviation of 2.09. The percentage of independent directors on an average board was 14,55 per cent. The highest percentage of women representation on boards was 43 per cent. 100 percent of the sample companies had a sustainability committee to deal with carbon disclosure-related issues.

The average of Risk Operation had 16,2\% towards carbon disclosure issue. The average emission accounting 
had $22,86 \%$. The Verification and trading has average standard $8, ! \%$. the highest percentage performance on carbon risk management was $60 \%$ and the average percentage governance on carbon risk management was $16 \%$, which mean all companies has good corporate governance very good. It is also seen that almost all companies meet the criteria in the green strategy checklist, only a few criteria that are not fulfilled because the sample of companies taken is the SRI KEHATI index.

Table II

Descriptive Statistics

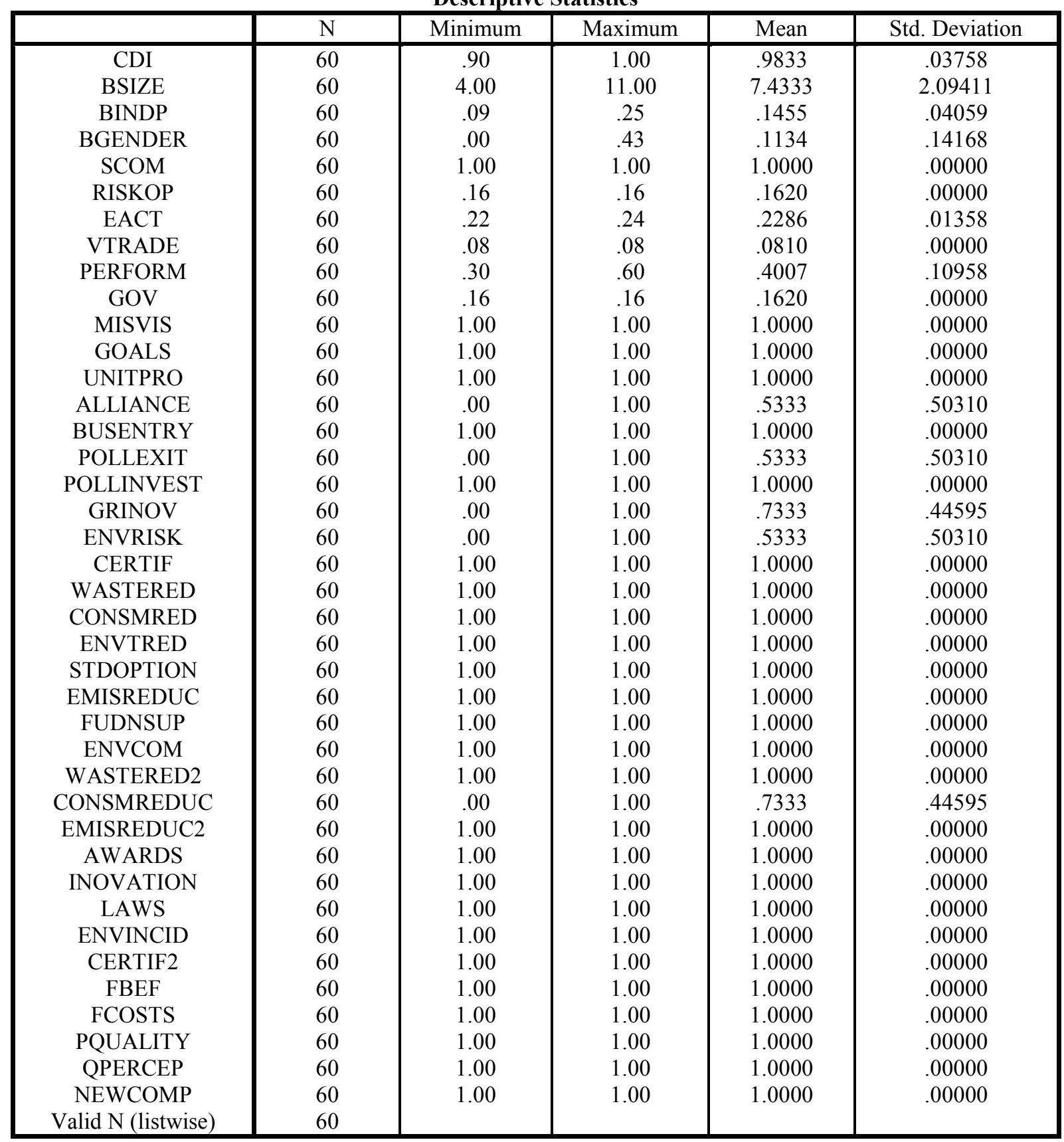

4.2 $\mathrm{F}$ analysis

The F statistical test is used to find out whether the regression model is feasible to use in the study (Ghozali, 2013). This test is done by comparing the significance value of $F$ test results with the level of significance used (0.05). In addition it show the relationship between carbon emission disclosure, green strategy and corporate governance \& carbon risk management was signifikan 
Table III

ANOVA ${ }^{\mathrm{a}}$

\begin{tabular}{|ll|r|r|r|r|r|}
\hline Model & & Sum of Squares & df & Mean Square & F & Sig. \\
\hline 1 & Regression & .032 & 10 & .003 & 3.057 & $.004^{\mathrm{b}}$ \\
& Residual & .051 & 49 & .001 & & \\
& Total & .083 & 59 & & & \\
\hline
\end{tabular}

a. Dependent Variable: CDI

b. Predictors: (Constant), ENVINCID, BGENDER, ALLIANCE, PERFORM, ENVRISK, GRINOV, EACT, POLLEXIT, BINDP, BSIZE

\subsection{Hypothesis analysis}

The data was based upon the years from 2016 and 2017. The result shows that SCOM, RISKOP, VTRADE, EACT and GOV has positive significant impact to carbon emission disclosure, which mean all variables on carbon risk management has positif significant impact towad carbon emission disclosure. In addition green strategy also has positive impact toward carbon emission disclosure. This order aligns with the assumption that high polluting firms are more likely to disclose emissions and environmental information than low polluting firms. Beside that BSIZE, BINDP, BGENDER and significant towards carbon emission disclosure. In addition green strategy also has significant result toward carbon risk management.

Tabel IV

\begin{tabular}{|c|c|c|c|c|c|c|c|c|c|c|}
\hline \multicolumn{11}{|c|}{ Model Summary } \\
\hline \multirow[b]{2}{*}{ Model } & \multirow[b]{2}{*}{$\mathrm{R}$} & \multirow[b]{2}{*}{$\begin{array}{c}\mathrm{R} \\
\text { Square }\end{array}$} & \multirow[b]{2}{*}{$\begin{array}{c}\text { Adjusted R } \\
\text { Square }\end{array}$} & \multirow[b]{2}{*}{$\begin{array}{l}\text { Std. Error } \\
\text { of the } \\
\text { Estimate }\end{array}$} & \multicolumn{5}{|c|}{ Change Statistics } & \multirow[b]{2}{*}{ Durbin-Watson } \\
\hline & & & & & $\begin{array}{c}\text { R } \\
\text { Square } \\
\text { Change }\end{array}$ & $\begin{array}{c}\text { F } \\
\text { Change }\end{array}$ & df1 & df2 & $\begin{array}{l}\text { Sig. F } \\
\text { Change }\end{array}$ & \\
\hline 1 & $.620^{\mathrm{a}}$ & .384 & .259 & .03236 & .384 & 3.057 & 10 & 49 & .004 & .764 \\
\hline
\end{tabular}

a. Predictors: (Constant), ENVINCID, BGENDER, ALLIANCE, PERFORM, ENVRISK, GRINOV, EACT, POLLEXIT, BINDP, BSIZE

b. Dependent Variable: CDI

\subsection{Discussion}

From the description above, it can be seen the characteristics of corporate governance, green strategy and carbon risk management from the disclosure of carbon emissions listed on the IDX through regression analysis on companies listed on the IDX based on the 2016-2017 SRI-KEHATI index. The results show that ENVINCID, BGENDER, ALLIANCE, PERFORM, ENVRISK, GRINOV, EACT, POLLEXIT, BINDP, and BSIZE chose a significant positive impact on the CDI. The results of this study are in line with the research conducted by Liao et al. (2015), Yunus et al. (2016) and Ben-Amar et al. (2017).

Corporate Governance through BINDP and BSIZE has a positive impact due to the importance of the role of the board of directors in a company, including the role of an independent director who controls the manager. The results of this study contradict the research of Ben-Amar et al. (2017) report an insignificant relationship between board size and carbon emissions disclosure.

There are many supporting factors related to the significant relationship between corporate governance, green strategy, and carbon risk management on carbon emissions disclosure. In the Sri-Kehati index, it is seen that large companies that have adequate directors, according to Cornier and Gordon (2001), have large companies that exert more external control than small companies because accountability and visibility as they are are more likely to disclose environmental information. In addition, reporting on disclosure of corporate carbon emissions is part of the overall carbon mitigation activities involving large investments so that most are carried out by large-scale companies that have long-term commitment and the establishment of carbon management systems (Luo et al., 2013).

On the other hand, BGENDER and SCOM have a negative relationship with disclosure, which has a nonsignificant impact on the CDI. Thus, insignificant results may be caused by the lack of contribution from female directors in each company, not even all companies have female directors other than that the level of sustainability of company committees in Indonesia is very low.In this study, the green strategy is calculated by completing a list of green strategies, namely strategic processes, implementation, strategy development, environmental performance, and financial competitive performance.

The green strategy implementation of the disclosure of carbon emission gas is supported by various factors, for example social strategies based on public demand because environmental issues will be integrated into the 
company's mission and vision, then the company's portfolio strategy in order to diversify into the green business. Third, companies try to leave pollutant businesses or sign strategic alliances for green purposes to support green businesses. Fourth, organizational strategies for green organizational units must be developed in the organizational structure including the human resources they have. Fifth, the company's financial strategy in making decisions to choose green investment rather than other alternative investments. Finally, differentiation or cost leadership strategies that have competitive advantages that show companies acting in green business.

\section{Conclusion}

The greenhouse effect and global warming is a phenomenon of increasing global temperatures from year to year due to increasing gas emissions such as carbon dioxide $(\mathrm{CO} 2)$, methane $(\mathrm{CH} 4)$, dinitrooxide (N2O), and chlorofluorocarbons (CFC), according to Riebeek (2010) referred to as emissions greenhouse gas (GHG)) so that solar energy is trapped in the Earth's atmosphere. One of the vision and mission SRI KEHATI is going concern, which believing that all generations have the fundamental right to a reasonable life and a balanced environment in the long run. KEHATI upholds the principles of sustainable development by always paying attention to the carrying capacity of the environment, improving the economy of the community, and intergenerational interests, behaviors that maintain the balance of the ecosystem, and the sustainability of life. The results of this study also reveal that companies are more likely to have independent directors in the company to do better dick on the company's performance. In addition, the results of a number of companies found in the Sri-Kehati index are generally very responsive in disclosing carbon emissions.

First, this study has a contribution to examine the level of disclosure of carbon emissions in developing countries including Indonesia. Thus, there are various determinants to support disclosure of carbon emissions, among others, stakeholders in the company that are expressed through GCG, green strategy, and carbon risk management variables to recognize the motivation to report such disclosures. The characteristics that support disclosure of carbon emissions, namely the number of board of commissioners and the impact of the board's gender diversity on disclosure of carbon emissions have been investigated previously, so this study supports the previous literature by providing evidence of the relationship between board number and board's gender diversity on carbon emissions disclosure.

This study also contributes in supporting the literature in the first study to look at the effect of carbon risk management on carbon emissions disclosure. This is because selali companies have conflicts between sociopolitical and economic disclosure theories, so that previously there was no relationship between carbon risk management and carbon disclosure. So this research adds new literature where carbon risk management has a positive relationship to carbon emissions disclosure.

The company's responsibility for the environment is dominated by external companies where stakeholder groups and the public are urging and demanding the company in matters of concern to address the issue of global warming. According to Graule and Gotthardt (2016) All companies from various industries must be responsible for managing and reducing carbon emissions gas, especially for industries whose primary fuel comes from fossils. Ben-Amar et al., (2017) revealed that the measurement and disclosure of carbon emission gas emissions is carried out as a first and significant step towards overcoming the problem of climate change and global warming. This study reveals that the relationship between corporate governance, green strategy, and carbon risk management on the level of disclosure of carbon emissions is significant because it uses samples from the SRI-KEHATI index, where companies have good quality in terms of corporate governance and concern for the environment for their business .

On the other hand, the regulatory body must take the steps needed to require all companies to reduce carbon emissions, the government must apply this to all industries without exception. The disclosure of carbon emissions must be captured in the annual report so that stakeholders are able to see carbon emission strategies for compliance with carbon emissions. Through this research, it is expected that the government must also report on corporate governance and obligations to the environment and how to manage the impact of environmental pollution.

The issue of global warming is related to climate change and global warming is a problem that requires support from various parties, including government, companies, NGOs and green groups. In this case, the company must be sensitive to problems related to climate change and global warming where each company strategy selection must consider the sustainability of the green environment. The obligation of NGOs and green groups is to increase public awareness also contribute to supervising companies in their strategies.

The results of this study have implications for companies that have a company size in supporting investment in a green environment. The company also has an obligation to be more transparent in providing reports to the public in the disclosure of carbon emissions and activities that affect the issue of global warming. According to Rankin et al., (2011) the role of the environmental committee to increase awareness of the importance of reporting carbon emissions disclosures aimed at reducing risk and business strategies related to global warming.

Other theoretical implications that support the basic arguments of agency theory are to reveal the factors that influence disclosure of carbon emissions. All companies include stakeholders, such as the public and government, 
green strategies, and carbon risk management are interrelated in exercising control over the company's business operations in an effort to reduce carbon emissions disclosure reporting through annual reports and sustainability.

\section{References}

Lee, S.P. and Devi, S.S. (2014), "The influence of governance structure and strategic corporate social responsibility toward sustainability reporting quality”, Business Strategy and the Environment, Vol. 23 No. 4, pp. 217-235.

Baltagi, B.H. (2001), Econometric Analysis of Panel Data, John Wiley and Sons, Chicester.

Barako, D.G. and Brown, A.M. (2008), "Corporate social reporting and board representation: evidence from the kenyan banking sector", Journal of Management\&Governance, Vol. 12 No. 4, pp. 309-324.

Bear, S., Rahman, N. and Post, C. (2010), "The impact of board diversity and gender composition on corporate social responsibility and firm reputation”, Journal of Business Ethics, Vol. 97 No. 2, pp. 207-221.

Ben-Amar, W., Chang, M. and McIlkenny, P. (2017), "Board gender diversity and

corporate response to sustainability initiatives: evidence from the carbon disclosure project", Journal of Business Ethics, Vol. 142 No. 2, pp. 369-383.

Blau, P.M. (1977), Inequality and Heterogeneity, Free Press, New York, NY.

Campbell, K. and Mínguez-Vera, A. (2008), "Gender diversity in the boardroom and firm financial performance", Journal of Business Ethics, Vol. 83 No. 3, pp. 435-451.

Chithambo, L. and Tauringana, V. (2014), "Company specific determinants of greenhouse gases disclosures", Journal of Applied Accounting Research, Vol. 15 No. 3, pp. 323-338.

Choi, B.B., Lee, D. and Psaros, J. (2013), "An analysis of australian company carbon emission disclosures", Pacific Accounting Review, Vol. 25 No. 1, pp. 58-79.

Coffey, B.S. and Wang, J. (1998), "Board diversity and managerial control as predictors of corporate social performance", Journal of Business Ethics, Vol. 17 No. 14, pp. 1595-1603.

Cormier, D. and Gordon, I.M. (2001), "An examination of social and environmental reporting strategies", Accounting, Auditing \& Accountability Journal, Vol. 14 No. 5, pp. 587-616.

Del Bosco, B. and Misani, N. (2016), "The effect of cross-listing on the environmental, social, and governance performance of firms", Journal of World Business, Vol. 51 No. 6, pp. 977-990.

Depoers, F., Jeanjean, T. and Jérôme, T. (2016), "Voluntary disclosure of greenhouse gas emissions: contrasting the carbon disclosure project and corporate reports", Journal of Business Ethics, Vol. 134 No. 3, pp. 445-461.

Estélyi, K.S. and Nisar, T.M. (2016), "Diverse boards: why do firms get foreign nationals on their boards", Journal of Corporate Finance, Vol. 39 No. 4, pp. 174-192.

Freedman, M. and Jaggi, B. (2005), "Global warming, commitment to the Kyoto protocol, and accounting disclosures by the largest global public firms from polluting industries", The International Journal of Accounting, Vol. 40 No. 3, pp. 215-232.

Frias-Aceituno, J.V., Rodriguez-Ariza, L. and Garcia-Sanchez, I.M. (2013), "The role of the board in the dissemination of integrated corporate social reporting", Corporate Social Responsibility and Environmental Management, Vol. 20 No. 4, pp. 219-233.

Gonzalez-Gonzalez, J.M. and Ramírez, C.Z. (2016), "Voluntary carbon disclosure by spanish companies: an empirical analysis", International Journal of Climate Change Strategies and Management, Vol. 8 No. 1, pp. 57-79.

Grauel, J. and Gotthardt, D. (2016), "The relevance of national contexts for carbon disclosure decision of stocklisted companies: a multilevel analysis", Journal of Cleaner Production, Vol. 133,pp. 1204-1217.

Guenther, E., Guenther, T., Schiemann, F. and Weber, G. (2016), "Stakeholder relevance for reporting explanatory factors of carbon disclosure", Business and Society, Vol. 55 No. 3, pp. 361-397.

Harjoto, M., Laksmana, I. and Lee, R. (2015), "Board diversity and corporate social responsibility”, Journal of Business Ethics, Vol. 132 No. 4, pp. 641-660. Hollindale, J., Kent, P., Routledge, J. and Chapple, L. (2017), "Women on boards and greenhouse gas emission disclosures", Accounting and Finance, doi: 10.1111/acfi.12258.

Hussain, N., Rigoni, U. and Orij, R.P. (2016), "Corporate governance and sustainability performance: analysis of triple bottom line performance", Journal of Business Ethics, doi: 10.1007/s10551-016-3099-5.

Jizi, M.I., Salama, A., Dixon, R. and Stratling, R. (2014), "Corporate governance and corporate social responsibility disclosure: evidence from the US banking sector”, Journal of Business Ethics,Vol. 125 No. 4 , pp. 601-615.

Kiliç, M., Kuzey, C. and Uyar, A. (2015), "The impact of ownership and board structure on corporate social responsibility (CSR) reporting in the Turkish banking industry", Corporate Governance:

The International Journal of Business in Society, Vol. 15 No. 3, pp. 357-374. Kolk, A., Levy, D. and Pinkse, J. (2008), "Corporate responses in an emerging climate regime: the institutionalization and commensuration of carbon disclosure", European Accounting Review, Vol. 17 No. 4, pp. 719-745. 
Kuo, L. and Chen, V.Y.J. (2013), "Is environmental disclosure an effective strategy on establishment of environmental legitimacy for organization?”, Management Decision, Vol. 51 No. 7, pp. 1462-1487.

Lee, S.Y., Park, Y.S. and Klassen, R.D. (2015), "Market responses to firms' voluntary climate change information disclosure and carbon communication", Corporate Social Responsibility and Environmental Management, Vol. 22 No. 1, pp. 1-12.

Liao, L., Luo, L. and Tang, Q. (2015), "Gender diversity, board independence, environmental committee and greenhouse gas disclosure”, The British Accounting Review, Vol. 47 No. 4, pp. 409-424.

Luo, L., Lan, Y.C. and Tang, Q. (2012), "Corporate incentives to disclose carbon information: evidence from the CDP global 500 report”, Journal of International Financial Management \& Accounting, Vol. 23 No. 2, pp. 93-120.

Luo, L., Tang, Q. and Lan, Y.C. (2013), “Comparison of propensity for carbon disclosure between developing and developed countries: a resource constrained perspective", Accounting Research Journal, Vol. 26 No. 1, pp. 6-34.

Miller, T. and Triana, M.D.C. (2009), "Demographic diversity in the boardroom: mediators of the board diversityfirm performance relationship", Journal of Management Studies, Vol. 46 No. 5, pp. 755-786. Ministry of Environment and Urbanization (MoEU) (2012), "Regulation on monitoring of greenhouse gas emissions", available at: www.resmigazete.gov.tr/eskiler/2012/04/20120425-6.htm (accessed 1 August 2017).

Naser, K., Al-Hussaini, A., Al-Kwari, D. and Nuseibeh, R. (2006), "Determinants of corporate social disclosure in developing countries: the case of Qatar", Advances in International Accounting, Vol. 19, pp. 1, pp. 1-23.

Prado-Lorenzo, J.M. and Garcia-Sanchez, I.M. (2010), "The role of the board of directors in disseminating relevant information on greenhouse gases", Journal of Business Ethics, Vol. 97,No. 3, pp. 391-424.

Prado-Lorenzo, J.M., Rodríguez-Domínguez, L., Gallego-Álvarez, I. and García-Sánchez, I.M. (2009), "Factors influencing the disclosure of greenhouse gas emissions in companies world-wide", Management Decision, Vol. 47 No. 7, pp. 1133-1157.

Rankin, M., Windsor, C. and Wahyuni, D. (2011), “An investigation of voluntary corporate greenhouse gas emissions reporting in a market governance system: Australian evidence", Accounting, Auditing\& Accountability Journal, Vol. 24 No. 8, pp. 1037-1070.

Reid, E.M. and Toffel, M.W. (2009), "Responding to public and private politics: corporate disclosure of climate change strategies", Strategic Management Journal, Vol. 30 No. 11, pp. 1157-1178.

Saka, C. and Oshika, T. (2014), "Disclosure effects, carbon emissions and corporate value", Sustainability Accounting, Management and Policy Journal, Vol. 5 No. 1, pp. 22-45.

Stanny, E. and Ely, K. (2008), "Corporate environmental disclosures about the effects of climate change", Corporate Social Responsibility and Environmental Management, Vol. 15 No. 6, pp. 338-348.

Yunus, S., Evangeline, E.T. and Abhayawansa, S. (2016), "Determinants of carbon management strategy adoption: evidence from Australia's top 200 publicly listed firms”, Managerial Auditing Journal, Vol. 31 No. 2, pp. 156-179. Further reading 